\title{
Effect of Bank Innovation Capability Dimensions on Market Share of Small and Medium Scale Enterprises in Nigeria
}

\author{
Omagu I. E., Asikhia O. U., Akinlabi H. B, Makinde G.O.
}

\begin{abstract}
The high failure rate of small and medium sized enterprises (SMEs) in Nigeria, has prompted banks, in response to both regulation and changing market dynamics, to resort to innovating around their structures, systems and processes to design products and processes that could help in reducingSMEs' failure rate. Thus, this study investigated the effect of bank innovation capability on the market share of small and medium enterprises in Nigeria. Cross-sectional survey research design was adopted, 5,292 and 27,000 staff of banks with dedicated SMEs' desks and SMEs' owner managers respectively were sampled and data collated. Multiple regression analysis was adopted and the result shows that bank innovation capability had positive significant effect on market share $($ Adj.R2 $=0.175, F(5,493)=22.054, p<0.05)$. It was concluded that bank innovation capability affect the market share of small and medium enterprisesand it was recommended that deposit money banks' managers should extend bank innovation capability dimensions ideas to SMEs' owners in Nigeria as increased market share can expand their capacities to reach new customers and markets.
\end{abstract}

Index Terms - Bank innovation capability, Market share, Small and medium scale enterprises, Banks.

\section{INTRODUCTION}

Performance of SMEs has received significant attention in different countries of the world. This has propelled governments in both developed and developing economies to direct huge investments towards the eventual growth of SMEs. Fundamental policies and programmes that improve the performance of SMEs were thus developed in many countries and these have led to the capacity of SMEs making significant contributions in terms of job creation, technological innovations, increased national output, as well as the promotion of exports amongst other contributions. Efforts have also been made by the Central Bank of Nigeria (CBN) through the deposit money banks in the country to provide funding and business advisory to the SMEs. However, despite these positive efforts, contributions, and interventions,

Omagu I. E., Department of Business Administration and Marketing ,School of Management Sciences, Babcock University, Ilishan-Remo, Nigeria

Asikhia O. U., Department of Business Administration and Marketing ,School of Management Sciences, Babcock University, Ilishan-Remo, Nigeria

Akinlabi H. B, Department of Business Administration and Marketing ,School of Management Sciences, Babcock University, Ilishan-Remo, Nigeria

Makinde G.O., Department of Business Administration and Marketing ,School of Management Sciences, Babcock University, Ilishan-Remo, Nigeria it is observed that many SMEs do not survive the first few years of existence due to the fast-changing and increasingly competitive landscape and the dynamism of the global market. Besides, the operating environment of these SMEs is facing tremendous changes, andintense competition in the area of innovation, deliverables and technological advancements which often affect the extent to which they perform and remain competitive. These observations, therefore, play a huge part in the decline of performance and eventual demise of some of these SMEs.

In Nigeria, SMEs have played significant roles in enhancing diversification and expansion of the industrial base, utilization of local materials and skills, increased government revenue, wealth creation, poverty reduction and curbing rural-urban migration amongst others. Specifically, in 2002, $98 \%$ of all businesses in the manufacturing sector were SMEs operating in Nigeria, providing $76 \%$ of the workforce and $48 \%$ of all the industrial output in terms of value-added (Eniola\&Ektebang, 2014). SMEs also employ $87.9 \%$ of the workforce in the private sector (Olukayode\&Somoye, 2013). In the agricultural and manufacturing sectors, SMEs employ more than 80\% (Eniola\&Ektebang, 2014). Despite their significance, studies indicate that majority of newly established SMEs fail to survive their first two years while existing ones are either shutting or operating at sub-optimal levels (Effiom\&Edet, 2018; Ndeye, Razak, Nagayev, \& Adam, 2018). One of the two most identified factors for SMEs challenges is unresponsiveness to the demands of innovation (Dimoji\&Onwuneme, 2016).

Beside the facts that deposit money banks have a lukewarm attitude towards loans and provision of advisory to the SME sector due to poor presentation of loan requests, inadequate collateral and the speculative nature of their cash flow streams (Mordi, 2016), disruption of the competitive landscape by digital technologies presented engendered external factor-induced strategies and restructuring of bank business models down the pyramid of the banking ecosystem to assists SMEs. According to Oboh and Ajibolade (2017), the approach banksadopted to assist the SMEs was to start with strategy formulation which includes innovation around existing structures, systems, processes, products, and marketing. Following this initiative, some banks created divisions specifically to drive SME business and provided dedicated staff who were given "holiday' from income performance pressure for a period ranging from one year to three years and the persons tasked with the responsibility for growing that market segment were mandated to design 
processes, products and systems that will support SME businesses' development and growth(John-Akamelu\&Muogbo, 2018). It is against this background that this paper seeks to examine the effect of bank innovation capability dimensions on the market share of small and medium scale enterprises in Nigeria.

\section{LITERATURE REVIEW}

This section discusses innovation capability dimensions (process, product, open, marketing, and organizational innovations) and market share.

\section{A. Conceptual Review}

\section{Bank Innovation Capability}

Bank innovation capability is the bank's potential in generating new and unique values by converting new idea procured (Naala, et al., 2017). Zhang (2004) described innovation capabilities as the combination of firm abilities to integrate and build resources to develop new products and processes, improve existing products and processes, and new product to market to provide an advantage towards achieving superior performance. According to Agyei-Mensah (2016), innovation capability refers to the internal driving energy to generate and explore new ideas and concepts, to experiment with solutions for potential opportunity patterns detected in the market and the ability to develop them into marketable and effective innovations, leveraging internal and external resources and competencies. Agyei-Mensah (2016) stated that the scope of innovation capability consists of technical innovation and administrative innovation. The scope is Technical innovations which include products, marketing, services, and the technology used to produce products, product sales, or render services directly related to the basic work activity of an organization. Administrative innovation pertains to organizational structure and administrative processes, indirectly related to the basic work activity of the organization and is more directly related to its management. The scope adopted for this paper include process, product, open, marketing, and organizational innovations.

Product innovation refers to the new or improved product, equipment or service that is successful on the market. Product Innovation refers to the introduction of goods and services that is new or significantly improved for its intended usage that may include the technical specification, components and materials, incorporated software or other characteristics their-in. it utilizes new knowledge or technologies, or a combination of both existing knowledge and technologies (Ogbonna, 2013).

A process innovation entails the implementation of a new or enhanced manufacturing or distribution process, or a new course of social service. Product and Process innovations are interconnected and interwoven to meet certain production targets. Process innovation is the implementation of a new or significantly improved method of production or delivery. This includes significant changes introduced in techniques, equipment or software that are employed during the innovation phase (Oslo, 2005). Concerning process innovation activities, similar patterns can be found as those for product innovations (Rouse,2013). Distinctive process innovation behaviours emerge for different sectors and firms size classes, where firms in the manufacturing sector and SMEs with more than 10 employees introduced significantly more process innovations than firms in other sectors or size classes.

Marketing innovation is the implementation of a new marketing method which has significant changes in its product design or packaging, product placement, product promotion or pricing to address customer needs, opening up new markets, or newly positioning the firm's product on the market, to increase the firm's sales (Oslo, 2005). The purpose here is to identify (new) potential market and (new) ways to render service to target markets through different methods of sales. Marketing innovation is the implementation of a new marketing method involving significant changes in product design or packaging, product placement, product promotion or pricing (OECD, 2005).

Organizational innovation is the implementation of a new method in the firm's business practices, workplace organization or external relations. They are mostly intended to increase a firm's performance by reducing administrative costs or transaction costs, improving workplace satisfaction (and thus labour productivity), gaining access to no tradable assets (such as non-codified external knowledge) or reducing costs of supplies (Oslo, 2005). To create an innovative organization, attention should be focused on two strategies directed; first, improving each employee's understanding of what innovation is and how the organization is committed to that objective, and second, developing organizational strategies that promote innovation.

Open innovation" means the firm is open to innovation in collaboration with outsiders. In the systems-wide paradigm, "open and collaborative innovation" means the innovation is open for use without proprietary restrictions. This can be broadly categorized into two: inbound and outbound. Inbound innovation is concerned with a firm leveraging on the discoveries of others, abandoning the idea of relying merely on the firm's internal R\&D (Chesbrough et al. 2006). Inbound open innovation evaluates the degree to which a firm accesses available external technologies to compliment the ones it already possesses (Chesbrough \& Crowther 2006; Hung \& Chou 2013; Lichtenthaler2009; Spithoven, Clarysse\&Knockaert2010). This includes acquiring external knowledge, in-sourcing (or licensing-in), joint R\&D, mergers and acquisition or strategic alliance and end-user involvement (Hung \& Chou 2013). Outbound open innovation on the other hand is concerned with firm exploiting technology capabilities by leveraging on external paths of commercialization (Chesbrough 2003a). In another word, outbound open innovation is an outward transfer of a firm's technological knowledge to outside firms to obtain monetary or non-monetary benefits (Lichtenthaler2009).

\section{Market Share}

According to Farris,Bendle, Pfeifer and Reibstein (2010), market share is the percentage of a market (defined in terms of either units or revenue) accounted for by an individual firm. In the opinions of Vargo and Lusch (2004), market share is a measure of how well a company has been able to predict market dynamics and the needs of the targeted customers. Significantly, the market share should be closely monitored 
for signs of change in the competitive scenery; this picture frequently drives strategic or tactical actions, since it is measured relative to the competitors' share of customer's wallet (Khantimirov, 2017). Market share provides the general idea about the size of a business organisation concerning its market and its competitors (Pulaj, Kume, \&Cipi, 2015). Similarly, Olanipekun, Abioro, Akanni, Arulogun and Rabiu (2015) elucidated market share as the percentage of an industry (defined in term of either units or revenue) acquired by a business entity over a specific period. Market share brings the added dimension of industry sales, and consequently, of competitive performance.

\section{B. Empirical Review}

Studies have empirically established the important role of innovation on market share in different sectors of various economies be it developed, emerging and developing economies. The studies of Tetteh and Essegbey (2015) and Tuan et al. (2016) established that firm innovation capability strategies have a positive and significant effect on firm market performance. Research findings of Mulinge and Kyongo (2017) empirically established that strategic innovation has positive and significant effected on the market performance of the commercial bank. The study findings support the blue ocean theory and resource-based view theory which explains the role of innovation and internal resources in organizational performance.

Iwu (2010) conducted to identify the relationships between the increase in market share through product development and innovation His study shown that product development and innovation initiatives are not just enough to secure that rewarding market share. Rather, amuch more comprehensible alignment of factors, and drivethe product development objective to meaningfulutilization of resources.Beyene, Shi and $\mathrm{Wu}$ (2016) examined the impact of innovation strategy on organizational learning and innovation performance with moderating factors of firm size and ownership type. The study revealed that innovation strategy is positively related to product innovation performance. Furthermore, firm size and ownership type moderate the effect of innovation strategy on product innovation performance.

Begonja, Čićek, Balboni and Gerbin (2016) examined the link between innovation and business performance determinants of SMEs. The results show that social innovators perceive their business performance to be higher than their competitors and are exporting significantly more than other firms, thus enhance the increase in market share. Kenfac, Nekoumanesh and Yang (2015) examined the impact of process innovation on organisational performance and established that process innovation has a significant positive impact on organisational performance in terms of financial and customer service performance. Shaughnessy (2015), however, categorized innovation in financial services into five distinct capabilities such as platform,content,strategy, leadership,and externalization.It was further argued that several financial institutions can adapt to changes in the industry, but much more lag behind and also lacks an understanding of these imminent characteristics. Hence, this study hypothesizes that:

$H_{0}$ : Bank innovation capability dimensions have no significant effect on market share of small and medium scale enterprises in Nigeria.

\section{Theoretical Review}

The theoretical perspective of this study is anchored on Diffusion of Innovation Theory and Technology Acceptance Model. Innovation diffusion theory opines that relative advantage, complexity, compatibility, trialability and observability are the factors influencing the adoption of innovation. The study considers that SMEs can gain and sustain its competitiveness to compete effectively in its industry through innovation. Innovation diffusion theory opines that relative advantage, complexity, compatibility, trialability and observability are the factors influencing the adoption of innovation. The study considers that SMEs can gain and sustain its competitiveness to compete effectively in its industry through innovation. The main limitations of Rogers's theory of adoption of innovation were that he built a set of stages which described the diffusion process, and he explained the factors, which could influence the adoption process, in general terms.

Technology Acceptance Model developed by Davis (1986) is based on the belief that the use and acceptance of an innovation are determined by the behavioural intention, but on the other hand, that the behavioural intention is determined by the individual's attitude towards the use of the innovation and also by his perception of its utility. It suggests that the acceptance of an innovation is determined by perceived usefulness and perceived ease of use. The technology of Acceptance Model is a theory that relates to this study as the study looks at the relationship between bank innovation and performance of SMEs and tries to also determine the organizational factors that promote the adoption of innovation. The Technology Acceptance Model is not without its critics. It had some limitations which reduced its efficiency to investigate the adoption of IT (innovation), the most common being its very simple and stingy characteristics (Chau \& Hu, 2001). Benbasat and Barki (2007) indicated that TAM diverted researchers' attention away from other important research issues and created an illusion of progress in the accumulation of knowledge.

\section{Conceptual Framework}

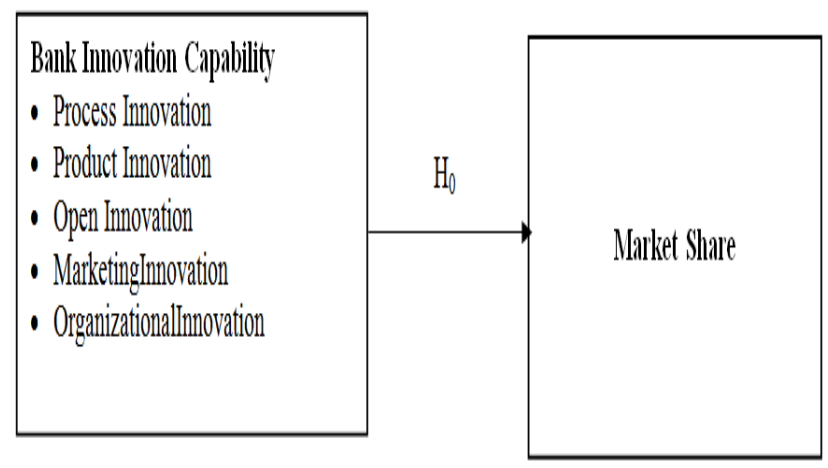

Figure - 1: Bank Innovation Capability and Market Share

Source: Developed by the researchers for the study 


\section{METHODOLOGY}

The study adopted cross sectional survey research design. The adoption of this design is consistent with the studies of various scholars (Akimehmeti, \&Prifti, 2017; Chepkulei, Ngugi, \&Walobwa, 2013; Ciabuschi, \&Azar, 2016; Ihi, Piller, $\&$ Wagner, 2012). Population of this study covers 5,292 and 27,000 staff of banks with dedicated SMEs' desks and SMEs' owner managers, respectively. However, the sample size consists of the 701 and 763 banks' advisors and owner managers respectively determined using Cochran formula. The study adopted stratified sampling technique. The main goal of using stratified sampling in this research was to divide the population into two groups. Then a probability sample (usually a random sample) is drawn from each group. The research instrument that was used in this study is adapted questionnaires. In the questionnaire, bank innovation capability is the independent variable, and its sub-variables are product innovation, process innovation, marketing innovation, open innovation, and organizational innovation. The dependent variable is competitive advantage. The questionnaires were validated, and properly tested for reliability using internal consistency method. The Cronbach's Alpha ranged between 0.71 and 0.93 . The items in the questionnaire were measured on a 6-point-type Likert scale of $\operatorname{Very} \operatorname{High}(\mathrm{VH})=6$, High $(\mathrm{H})=5$, Moderately High $(\mathrm{MH})=4$, Moderately Low $(\mathrm{ML})=3$, Low $(\mathrm{L})=2$ and Very Low $=1$. The model specified is represented below.

$\mathrm{MS}=\mathrm{f}(\mathrm{PI}$, PrI $, \mathrm{MI}, \mathrm{OI}, \mathrm{OpI})$ Regression
Transforming equation 1 to econometric model, we have: $\mathrm{MS}=\alpha_{0}+\beta_{1} \mathrm{PI}+\beta_{2} \mathrm{PrI}+\beta_{3} \mathrm{MI}+\beta_{4} \mathrm{OI}+\beta_{5} \mathrm{OpI}+\mu_{\mathrm{i}}$ Where:

$\alpha_{0}=$ Constant term

MS = Market share

PI = Product Innovation

PrI $=$ Process Innovation

MI = Market Innovation

$\mathrm{OI}=$ Open Innovation

OpI= Organizational Innovation

$\beta_{1}, \beta_{2}, \beta_{3}, \beta_{4} \& \beta_{5}=$ Coefficients of Explanatory Variables $\mu_{\mathrm{i}}=$ Error term

\section{Apriori Expectation of the Result}

The study proposes that an increase in the independent variables bank innovation capability will increase market share of SMEs. This can be mathematically stated as follows: $-\beta_{1}, \beta_{2}, \beta_{3}, \beta_{4} \& \beta_{5}>0$

\section{RESULTS AND DISCUSSION}

A total of 1,304 copies of questionnaire were administered to 701 bank employees and 763 owners/managers of SMEs in Nigeria, respectively. Out of 1,304 copies of questionnaire that were distributed, 1,039 (i.e., 499 copies from bank employees and 540 copies from owners/managers of SMEs) were correctly filled and returned. This represented $70.97 \%$ percent. Multiple regression analysis was used to analyse and test the hypothesis. The results of the analysis and parameter estimates obtained are presented in Table 1. equation $1 \mathrm{a}$

Table 1: Results of Regression of Bank Innovation Capability Dimensions on Market Share of Small and Medium Scale Enterprises in Nigeria

$\begin{array}{llll}\text { Variables } & \text { B } & \boldsymbol{T} & \text { Sig. } \\ \text { (Constant) } & 4.005 & 1.070 & .285 \\ & & & \\ \text { Product Innovation } & .281 & 2.557 & .011 \\ \text { Process Innovation } & .012 & .143 & .886 \\ \text { Organizational Innovation } & .586 & 5.805 & .000 \\ \text { Marketing Innovation } & -.012 & -.122 & .903 \\ \text { Open Innovation } & .108 & 1.356 & .176\end{array}$

a. Dependent Variable: Market Share

a. Predictors: (Constant), Open Innovation, Organizational Innovation, Process Innovation, Marketing Innovation, Product Innovation.

Source: Researcher's Field Results (2021)

Results in Table 1 showed that product innovation $(\beta=$ $0.281, \mathrm{t}=2.557, \mathrm{p}<0.05)$ and organizational innovation $(\beta=$ $0.586, \mathrm{t}=5.805, \mathrm{p}<0.05)$ have significant effect onmarket share of small and medium scale enterprises in Nigeria, while Process Innovation $(\beta=.012, \mathrm{t}=.143,>0.05)$ and Open Innovation $(\beta=.108, \mathrm{t}=1.356, \mathrm{p}>0.05)$ did not have significant effect on market share of small and medium scale enterprises. On the hand, market innovation $(\beta=-.012, \mathrm{t}=$ $-.122, p>0.05)$ has a negative and insignificant effect on market share of small and medium scale enterprises in Nigeria. This implied that product innovation and organizational innovation are determinants of market share of small and medium scale enterprises in Nigeria. The results further revealed that bank innovation capability dimensions accounted for $17.5 \%$ of the variances in market share of small and medium scale enterprises in Nigeria (Adj. $R^{2}$ of $0.175, \mathrm{p}$ $=0.000)$. The regression model however did not explain $82.5 \%$ of the variation inmarket share of small and medium scale enterprises in Nigeria, demonstrating that there are other factors associated with market share of small and medium scale enterprises in Nigeria, which were not captured in the current model. The results indicate that the overall model was statistically significant as $5 \%$ significance level implying that Bank innovation capability dimensions influences market share $(F(5,493)=22.054, \mathrm{p}<0.05)$. The established regression model for the construct is expressed as follows:

$\mathrm{MS} \quad 4.005+0.281 \mathrm{PI}+$

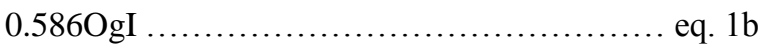

The regression equation above indicates that taking all 
factors constant at zero, market share of small and medium scale enterprises in Nigeria was 4.005. From the result, the regression coefficient of product innovationwas 0.281 , which implied that for every change in product innovation, there is a 0.281 increase in market share of small and medium scale enterprises in Nigeria. The regression coefficient of organizational innovation was 0.586 implied that unit change in organizational innovationeffect change in market share of small and medium scale enterprises. This implied that market share of small and medium scale enterprises in Nigeria will increase significantly with the improvement in product innovation and organizational innovationof the banks increased. The level of confidence for the analysis was set at $95 \%$. Based on the F statistics and adjusted coefficient of determination with p-value less than conventional probability of 0.05 , the null hypothesis $\left(\mathrm{H}_{0}\right)$ which states that bank innovation capability dimensions have no significant effect on market share of small and medium scale enterprises in Nigeria was rejected.

\section{DISCUSSION}

The results of the multiple regression analysis indicated that bank innovation capability dimensions had significant effect on market share of small and medium scale enterprises in Nigeria and provided an overall significant view. The finding of this study is consistent with studies of Tetteh and Essegbey (2015) and Tuan et al. (2016) who established that firm innovation capability strategies have a positive and significant effect on firm market performance. Research findings of Mulinge and Kyongo (2017) empirically established that strategic innovation has positive and significant effected on the market performance of the commercial bank. These findings supported the findings of the current research. Iwu (2010) conducted to identify the relationships between the increase in market share through product development and innovation. His study showed that product development and innovation initiatives are not just enough to secure that rewarding market share. The sharp differences in the findings of the study in relation to the past findings may be connected to the implementation of these innovations by the surveyed banks. Also, SMEs may lack adequate knowledge and awareness of the availability of these opportunities to utilize them for improved performance. Furthermore, Ajayi and Morton (2015) explored the Enablers of Organizational and Marketing Innovations in SMEs from South-Western Nigeria. The study revealed that Organizational and Marketing Innovations (OMIs) could be the necessary prerequisites to optimally utilize and deploy such process and product innovations. Similarly, the study identifies some enablers that can promote SMEs' OMIs capabilities, effective innovations, and organizational market survival. Susanto and Wasito (2017) studied the performance of SMEs through innovation strategies in developing countries. Their study revealed that innovation strategies enhance firm market performance.

\section{CONCLUSION AND RECOMMENDATIONS}

The study focused on the effect of bank innovation capability dimensions on the market share of small and medium scale enterprises in Nigeria, and the results revealed that innovation capability dimensions (product and organizational innovations) have significant and positive effect on market share.In view of the empirical findings, this study concluded that bank innovation capability dimensions (process, product, open, marketing, and organizational innovations) had significant effect on market share of SMEs performance in Nigeria. This study helps the banks and SMEs managers to identify the key innovation capability strategic dimensions that will enhance maximization of overall SMEs performance. It also provides adequate information on how SMEs in Nigeria can improve their overall performance through adoption of bank innovation capability creativities. The study recommended that deposit money banks' managers should extend bank innovation capability dimensions ideas to SMEs owners in Nigeria as increased market share can expand their capacities to reach new customers and markets.

\section{REFERENCES}

[1] Agyei-Mensah, B. K. (2016). Internal control information disclosure and corporate governance: evidence from an emerging market. Corporate Governance: The international journal of business in society. 5(2), 95-112.

[2]Ajayi, O. M., \& Morton, C. (2015).Exploring the enablers of organizational and marketing innovations in SMEs: Findings from south-western Nigeria.Sage Journal, January-March, 1-13.

[3] Akimehmeti, K. \&Prifti, L. (2017).A competency model for "Industrie 4.0" Employees. 13th International Conference on Wirtschaftsinformatik, 46-60.

[4] Annual Report (2005).The organization for economic co-operation and development (OECD) annual report.

[5]Begonja, M., Čićek, F., Balboni, B., \&Gerbin, A. (2016).Innovation and business performance determinants of SMEs in the Adriatic region that introduced social innovation. EkonomskaIstraživanja / Economic Research, 29(1), 1136-1149.

[6]Benbasat, I., \&Barki, H. (2007). Quo vadis TAM?. Journal of the association for information systems, 8(4), 7-22.

[7]Beyene, K. T., Shi, C. S., \& Wu, W. (2016). The impact of innovation strategy on organizational learning and innovation performance: Do firm size and ownership type make a difference? SouthAfrican Journal of Industrial Engineering, 27(1), 125-136.

[8]Chau, P. Y., \& Hu, P. J. H. (2001). Information technology acceptance by individual professionals: A model comparison approach. Decision sciences, 32(4), 699-719.

[9]Chepkulei, B., Ngugi, J., \&Walobwa, D. (2013). Effect of the type of innovation on the growth of small and medium enterprises in Kenya: a case of garment enterprises in Jericho, Nairobi. European Journal of Management Sciences and Economics, 1(2), 49-57.

[10] Chesbrough, H., \& Crowther, A. (2006). Beyond high tech: Early adopters of open innovation in other industries. Research and Development Management,36(3), 229-236.

[11] Ciabuschi, F. \& Azar, G. (2016). Organizational innovation, technological innovation, and export performance: The effects of innovation radicalness and extensiveness. International Business Review, 26(2), 324-336.

[12] Davis, F. D. (1985). A technology acceptance model for empirically testing new end-user information systems: Theory and results (Doctoral dissertation, Massachusetts Institute of Technology).

[13] Dimoji, F. A., \&Onwuneme, L. N. (2016).Small and medium scale enterprises and sustainable economic development in Nigeria. Proceedings of 33rd International Business Research Conference 4 5.

[14] Effiom, L., \&Edet, S. (2018). Success of small and medium enterprises in Nigeria: Do environmental factors matter? Journal of Economics and Sustainable Development, 9(4), 117-128.

[15] Eniola, A. A., \&Ektebang, H. (2014). SME firms performance in Nigeria: Competitive advantage and its impact. International Journal of Research Studies in Management, 3(2), 75-86.

[16] Farris, W., Bendle, N., Pfeifer, E., \&Reibstein, J. (2010).Marketing metrics: The definitive guide to measuring marketing performance.Pearson Education. 
[17] Hung, K., \& Chou, C. (2013). The impact of open innovation on firm performance: The moderating effects of internal $R \& D$ and environmental turbulence. Technovation, 33(3), 368-380.

[18] Ihi, C., Piller, T., \& Wagner, P. (2012).Organizing for open innovation: Aligning internal structure with external knowledge search. Journal of the Academy of Marketing Science,35(4), 475 - 491.

[19] Iwu, C. (2010). Impact of product development and innovation on market share.African Journal of business management, 4(13), 2659-2667.

[20] John-Akamelu, C. R., \&Muogbo, U. S. (2018).Role of small \& medium enterprises in poverty eradication in Nigeria. European Journal of Research and Reflection in Management Sciences, 6(2), 33-49.

[21] Kenfac, G. S., Nekoumanesh, S., \& Yang, M. (2013). Process innovation: Impacts on organisation's performance: A qualitative study of four Swedish Municipalities, published by school of economics, University of Linnaeus.

[22] Khantimirov, D. (2017). Market share as a measure of performance: Conceptual issues and financial accountability for marketing activities within a Firm. Journal of Research in Marketing, 7(3), 587-592.

[23] Lichtenthaler, U. (2009). Absorptive capacity, environmental turbulence, and the complementarity of organizational learning processes', Academy of Management Journal, 52(4), 822-846.

[24] Mordi, C. (2016). Entrepreneurship and Entrepreneurial Finance in Ghana.In Entrepreneurial Finance in Emerging Markets (pp. 345-360). Palgrave Macmillan, Cham.

[25] Mulinge, P., \&Kyongo, J. K. (2017).Strategic innovation and performance of commercial banks. International Journal of Economics, Commerce and Management, 5(7), 596-606.

[26] Naala, M., Nordin, N., \& Omar, W. (2017). Innovation capability and firm performance relationship: A study of PLS-structural equation modeling (PLS-SEM). International Journal of Organization \& Business Excellence, 2(1), 1-11.

[27] Ndeye, N. D., Razak, L. A., Nagayev, R., \& Adam, N. (2018) Demystifying small and medium enterprises'(SMES) performance in emerging and developing economies. BorSa Istanbul Review, 18(4), 269-281.

[28] Oboh, C. S., \&Ajibolade, S. O. (2017). Strategic management accounting and decision making: A survey of the Nigerian Banks. Future Business Journal, 3(2), 119-137.

[29] Ogbonna, J. C. (2013). Bioenergy production and food security in Africa.African Journal of Biotechnology, 12(5), 7147-7157.

[30] Olanipekun, W. D., Abioro, M. A., Akanni, L. F., Arulogun, O. O., $\&$ Rabiu, R. O. (2015).Impact of strategic management on competitive advantage and organisational performance - evidence from Nigerian bottling company.Journal of Policy and Development Studies, 9(2), 185-198.

[31] Oslo, M. (2005).Product, process, marketing and organizational innovation in industries of the flat knitting sector.RAI Revista de Administração e Inovação, 14(4), 321-332.

[32] Pulaj, E., Kume, V., \&Cipi, A. (2015).The impact of generic competitive strategies on organizational performance.The evidence from Albanian context.European Scientific Journal.11(28), 1857.

[33] Rouse, W. B. (2013). The conditions of complex innovation adoption occurrence.The Electric Journal Information System Evaluation, 16(5), 10-27.

[34] Shaughnessy, H. (2015). Innovation in financial services: The elastic innovation index report. Inno Tribe, 1-21.

[35] Spithoven, A., Clarysse, B., \&Knockaert, M. (2010).Building absorptive capacity to organise inbound open innovation in traditional industries. Technovation, 30(2), 130-141.

[36] Susanto, B \&Wasito, A. (2017). Improve the performance of SMES through innovation strategies in developing countries. International Journal of Scientific \& Technology Research, 6(10), 282-285.

[37] Tetteh, E. K., \&Essegbey, O. (2015).Firm-level innovation: The case of Ghanaian firms. European Journal of Business and Innovation Research, 2(2), 1-18.

[38] Tuan, N. P., Nhan, N., Giang, P., \& Ngoc, N. (2016).The effects of innovation on firm performance of supporting industries in Hanoi, Vietnam.Journal of industrial Engineering and Management, 9(2), 413-431.

[39] Zhang, L. (2004). Small area estimates for cross-classifications. Journal of the Royal Statistical Society, 66(2), 1-23. 